\title{
Post Office Box
}

National Cancer Institute

\section{Source}

National Cancer Institute. Post Office Box. NCI Thesaurus. Code C80235.

A numbered box in a post office where letters for a patron are kept until called for. 